Article

\title{
Sustainability of the Amazon Nut in Mato Grosso: An Application of the MuSIASEM Method
}

\author{
Thiago Vargas Maldonado ${ }^{1}$, , Francesca Allievi ${ }^{2}$ and Luiz Panhoca ${ }^{1, *}$ \\ 1 Social Applied Science Sector, Post-Graduation Accounting Program (PRPPG/UFPR), \\ Federal University of Paraná, Curitiba 80210-170, Brazil; maldonado_thiago@yahoo.com.br \\ 2 School of Business, JAMK University of Applied Sciences, Rajakatu 35, 40200 Jyväskylä, Finland; \\ francesca.allievi@jamk.fi \\ * Correspondence: panhoca@ufpr.br
}

check for updates

Citation: Maldonado, T.V.; Allievi, F.; Panhoca, L. Sustainability of the Amazon Nut in Mato Grosso: An Application of the MuSIASEM Method. Sustainability 2021, 13, 9777. https: / / doi.org/10.3390/ su13179777

\section{Academic Editors:}

Grigoris Giannarakis, Stella Despoudi and Nikolaos Sariannidis

Received: 14 July 2021

Accepted: 24 August 2021

Published: 31 August 2021

Publisher's Note: MDPI stays neutral with regard to jurisdictional claims in published maps and institutional affiliations.

Copyright: (C) 2021 by the authors Licensee MDPI, Basel, Switzerland. This article is an open access article distributed under the terms and conditions of the Creative Commons Attribution (CC BY) license (https:// creativecommons.org/licenses/by/ $4.0 /)$.

\begin{abstract}
The Amazon biome occupies $60 \%$ of Brazilian territory, configured as a complex metabolism due to its diversity and the history of occupation by humans in the exploitation of its services. The Amazon nut tree (Bertholletia excelsa) occurs in the entire Amazon biome, which is essential for its sustainability. The Amazon nut production chain in the northwest of the State of Mato Grosso presents itself as a relevant case of analysis of the extractive activity of non-timber forest products (NTFP). Based on interpretative assumptions, the multi-scale integrated analysis of societal and ecosystem metabolism (MuSIASEM) approach is applied to the data collected in a farmers' cooperative. The objective of this study was to analyze the socio-environmental metabolism of the productive chain of the Amazon nut in the northwest region of the Mato Grosso State (MT) in Brazil. As the MuSIASEM approach can generate an integrated set of indicators measured at different scales and dimensions of analysis, the results show a lack of sustainability in the social dimension, in the environmental dimension, and the presence of intermediaries that serve companies that function as an illegal part of the metabolism. As a next step, the defined method needs testing on different NTFPs and in other micronarratives.
\end{abstract}

Keywords: Amazon nut; non-timber forest products; domestic work overload; eco-efficiency; environmental accounting; life cycle assessment

\section{Introduction}

According to Schaafsma and Morse-Jones [1], the increased pressure on the natural environment requires that policymakers make choices about the trade-offs between ecosystem conservation and economic development. A key consideration in such decisions is how the costs and benefits of policy options are distributed, coupled with the complexity of conservation problems, which presents a significant challenge for managers and decision-makers in different stakeholders [2]. According to the Union of Concerned Scientists (UCS), humans and the natural world are on a collision course, and fundamental changes are urgent [3-5]. Human activities inflict harsh and often irreversible damage on the environment and its critical natural resources. If not checked, many of our current practices put at serious risk the future that we wish for human society and the plant and animal kingdoms, and may alter the living world up to the point that it will be unable to sustain life in the manner that we know.

Blignauta and Aronson [6] state that there is also a particular urgency to find better ways to account for environmental risks and to measure the possibly drastic consequences; for example, an increase in rainfall variability has been observed [7]. It has also become very relevant to find better ways to measure the metabolism between nature and humans, such as exploring non-timber forest products (NTFPs). NTFP products refer to uncultivated forest products such as roots, barks, stems, exudates, leaves, fruits, berries, fungi, seeds, etc. [8], which could improve business opportunities of local companies and support rural 
livelihoods [9]. All these operations have various kinds of effects on the local communities and the environment [10]. However, the social-ecological systems insufficiently operationalize and theorize the social system, which is a core dynamic within the metabolism of any social-ecological system [11].

We used the concept of metabolism to define how human activity perpetuates or fades over time. When considering Brazil, one of the metabolisms that compose it is the Amazon biome and the human activity taking place in there. To understand the complex Amazon environment, alternatives were sought to effectively cover the sustainability problem (social, economic, and environmental aspects) and the ecosystem services. These are defined as the aspects of ecosystems utilized (actively or passively) to produce human well-being to beneficiaries [12] and provided at different spatial and temporal scales. It means that different beneficiaries can have different and conflicting interests [13].

Deforestation is one of the main problems faced by the forest and the local communities, as NTFPs play an essential role in communities' survival, used for subsistence and economic purposes. In Brazil, the process of colonization of the Amazon began with the discovery of Brazil in 1500, but it only started to occur significantly in the 20th century. Since the 1970s, encouraging the region's occupation has attracted immigrants from various parts of the country [14-16]. The northwest of the State of Mato Grosso (MT) is particularly important in this context: its territory is composed of social groups with different political, economic, and social interests, such as local ethnicities (some in extinction), landowners, prospectors, land reform settlers, extractive workers and traders such those involved in the diamond chain, which constitute a complex metabolism $[14,17,18]$. The case study presented here is set in the region of the Amazon deforestation arc, also known as the arc of fire [19]. Estimates considering only legal deforestation show that in the year 2050, only the indigenous reserves and the reserve where this study was conducted will remain as a preserved forest [20].

With the consolidation of livestock and timber extraction, residents of the region incorporated the local indigenous culture. They then began to explore other locality characteristics, such as NTFPs including the Amazon nut, which constitutes an important source of income for Amazonian families and communities. Peters [21] said that some of the challenges regarding NTFP harvest are global. NTFPs are often labor intensive and, the collection locations and the seasonal behavior of crops, make this products a challenge for expansion [22].

The name Pará nut or Brazil nut, as it is popularly known, has its correct designation as Amazon nut since it is native to the Amazon biome (which encompasses seven countries), and in 1992 during the 3rd World Convention of Dried Fruits, held in Manaus, had its nomenclature agreed as "Amazon nut" [23]. In this work, we use the term Amazon nut, and the three designations are synonymous [23]. The Amazon nut is a fruit extracted from the Castanheira (Bertholletia excelsa), a tree found throughout the Amazon region; the gathering and use of the Amazon nut are historic and constitute an important activity for that society [24,25]. In Brazil, the Amazon nut is used in all states belonging to the Amazon biome.

Originated in the natural sciences, the concept of metabolism is also used to study social systems. Currently, its use refers to the consistency of the energy and material processes within societies and the economy. The concept echoed in social theories; however, its development gradually became more or less restricted with the oscillating interest of the researchers [26]. In the social sciences, the concept reappears in scientific discussions with the expansion of environmental issues in the 1960s, when criticism of unbridled economic growth allowed us to turn the attention of scholars to the concept of metabolism [26-31].

Different theoretical currents have been organized around this concept. For Newell and Cousins [32], it is possible to identify three main theoretical currents today for what the authors called "the three ecologies": industrial ecology, Marxist ecology, and urban ecology. Industrial ecology minimizes waste and converts by-products into reusable products or resources [33,34]. The Marxist ecology highlights, among crisis capitalist systemic 
tendencies, that a crisis of the natural conditions of human development is produced by the exhaustion of the sources of this system [12,35]. Urban ecology is an interdisciplinary, quantitative, and sizable description of an urban ecosystem, so designs and discoveries are easier to compare and repeat, and natural science research is developing on urban ecosystems, particularly in the field of ecology [36,37].

The industrial ecology approach was developed by Ayres and Kneese [27] and generally utilized material flow analysis (MFA) and life cycle assessment (LCA) methodologies [38]. In this line of thought, nature is used as a structural and functional model for analyzing industrial systems [39]. This current has two subdivisions, one called "traditional urban metabolism" and another the "Vienna School of Socioeconomic Metabolism," which differ from one another in that the temporal cuts in the first are generally transverse, while the second are longitudinal, in addition to the variables of an analysis which in the Vienna School considers the construction of societies via historical materialism.

In the current Marxist ecology, the concept of metabolism is applied to investigate themes that address the tensions between nature and society proposed by Marx [40], to the function of social power in the construction of urban space and access to goods [41], and the ruptures between the environment and human production action brought about by globalization and urbanization [42-44]. Urban political ecology is divided into two subcurrents that understand the concept of metabolism as active and networked circulations that rearrange physical and social environments in "socialist assemblies" [45]. Second, based on the metabolic rift theory [42,43], the concept of metabolism is developed to understand the relations between man-nature. However, the thought differs in being oriented to believe there is a metabolic rupture between rural and urban.

Urban ecology finally consolidates, as the third and most recent current established, a unique focus on urban environments (cities), and works on the concept of metabolism less constantly [32,46,47].

Several methods have been improved or built based on the theory of social metabolism and explain that the boundaries of these theoretical approaches are still flexible and that theory, as the very concept of the idea, is constantly adapting to reality.

We use the MuSIASEM approach as a guide to measuring the proposition of the article. MuSIASEM was introduced by Giampietro and Mayumi [47-49]. MuSIASEM was previously used to assess socio-environmental metabolism in an ecological reserve in Scotland [50], in the use of land in Cambodia [51], China [52], the Balearic Islands, Spain [53], in the energy systems of Brazil [54], and the use of water in Peru [55].

MuSIASEM is conceived in two main axes: (i) the semantic axis, the pre-analytic stage in which the structure of the representations of the systems is conceived, and (ii) the syntactic axis that comprises the selection, production, and use of indicators, and is where the analysis and benchmarks are appropriately implemented. According to Giampietro and Gamboa [56], the creation of indicators needs, fundamentally, to adequately define criteria and attributes (semantic categories) to be taken into account in the analysis and to elect formal hierarchies and rules of production, as well as proxies that are capable of providing adequate data for evaluations and determine causal relationships where appropriate.

What allows MuSIASEM to encompass different dimensions and different variables is the versatility of the instrument. When defining the semantic axis, the description of the narrative is made from a "multipurpose grammar," a process that will give meaning to the analysis of the system under study $[48,49,56,57]$. For this vocabulary, we use a preliminary definition of: (i) a taxonomy (the set of semantic categories and formal categories used in the grammar; (ii) a set of dictionaries for the elements of the different sets; (iii) a set of production rules to be applied to formal categories using the distinction between "tokens" and "names." Then, the production rules are associated with the formal inference system, determining the values of "names" starting from the data input [56]. Thus, this concept suggests the establishment of three component elements: a lexicon (semantic and formal classes); a set of production principles (syntactic and semantic rules to be used for class items, defining the structured set of relations); and the ability to apply the meta-tool $[56,57]$ 
The syntactic axis, in turn, is pointed by the quantitative relations to be realized from the establishment of the grammar of the narrative. Its concept, as based on GeorgescuRoegen's 'flow-fund' model [57], makes understood that industrial and agricultural activities do not obey the same economic laws and thus need to be individualized. Based on this understanding, Giampietro and Mayumi [57] conceive the flow-fund model of production and consumption processes where flows are understood as the elements that do not maintain their characteristics from the beginning to the end of the narrative and determine "what the system does," what the system processes.

Factors external to the system govern these flows, such as resource availability and internal factors [48,57]. The funds, in turn, cover the items that are fixed throughout the representation. The elements grouped in the background category must maintain their characteristic of metabolic converters and narrate "what the system is," the conjuncture in which the flows will be metabolized.

Funds will determine the rate of consumption of the flows and legitimize an entry and exit of the system; therefore, the funds must be renewed cyclically due to their fixity [57]. By incorporating the Georgescu-Roegen model, Giampietro and Mayumi [48,49] divided it into a multi-level matrix composed, as the name suggests, of several hierarchical levels of analysis that allow describing the metabolism with greater efficiency. The chosen background is then called a matrix, which is confronted with the flow(s) which the rules of production established in the proposed grammar allow. Thus, funds and flows allocated are labeled as "extensive variables"; i.e., indicators which represent volumes and characterize the size of the compartments.

When the production rules established in the semantic axis occur, the so-called "intensive variables" indicators are produced, which indicate the potential or pressure of metabolism. These variables mark the metabolic rate of a compartment under analysis (EMRi-exosomatic metabolic rhythm), defining when a flow is metabolized by a given fund and the intensive variables produced, which are then used as benchmarks to provide a qualitative view of these items [18,48,49,56-58].

The sum of the compartments listed in the matrix comprises the total of the extensive variables presented, which allows the application of the so-called 'Sudoku effect' (Sorman et al. 2009). In this way, these domains are forced to combine according to initial parameters, but not fixed, combining all the expected dimensions, one restrictive of the other $[18,56,59]$.

Following the methodology then allows the execution of the impredicative loop analysis (ILA). The term impredicativity [60] is defended by Giampietro and Mayumi and Ramos-Martin [57] in its use in MuSIASEM because without understanding this concept, the scientific activities within the field of sustainability are obscure. The unpredictability disrupts scientific reductionism when studying metabolisms since it is impossible to establish a common linear link in traditional scientific instruments. For a linear relationship to occur, it is necessary to arbitrate a narrative (as a single scale) that can avoid the influence of causal externalities on the intended result, since in complex systems where scales and hierarchies are essentially heterogeneous it is not effective since there will always be alternative ways to determine causality. In this way, it is possible to ascertain the feasibility of the exosomatic metabolisms of social complexes, evaluating the consistency of the values attributed to the flows and funds over two grammars that will determine the impredicative cycle: the consumption sector metabolism $(\mathrm{HH})$, which represents the demand for products and services, paid work (PW), and the metabolism of the productive sector (PS), which denotes the demand for PW and the supply of products and services [48,49]. Therefore, the ILA allows studying the viability and desirable patterns, biophysical and socioeconomic constraints within a proposed scenario [56].

The challenge is to verify the feasibility of using the method in micro analyses, since until recently the studies analyzed metabolisms of whole countries, as an exception to an attempt to this end in Scotland [50]. This study seeks to create benchmarks for similar narratives, which was impossible for micronarratives, especially in the Amazon context. 


\section{Method}

This research uses interpretative epistemology and is characterized as descriptiveexploratory with a qualitative approach and aims to analyze the socio-environmental metabolism of the Amazon nut production chain in the northwest of the State of Mato Grosso through the MuSIASEM approach [61-64]. Regarding the timing analysis, a crosscut with an ex post facto approach is used, and the year 2016 is analyzed in this case study. The MuSIASEM approach is integrated with interviews, documents, and secondary data $[49,64]$.

The method applied in this case study is the multi-scale integrated analysis of societal and ecosystem metabolism approach (MuSIASEM), which aims at characterizing sustainability in terms of economic and biophysical, social, and ecological metabolism at different scales. The approach of this article follows the work of Giampietro on the application of the MuSIASEM method $[48,49,65]$.

A case study methodology is often used in exploratory studies while preserving real-life events [66]. The present study is exploratory, and a case approach is suitable for studying phenomena with limited information due to its ability to combine primary and secondary data [66]. Additionally, case studies were applied previously to investigate the community's response to environmental changes $[67,68]$ and the pressure on the natural environment [69].

The case selected was the productive chain in the northwest state of Mato Grosso, primarily because of the importance of the activity in this region as an alternative to stop the deforestation that advances through this ecological corridor. Secondly, the activity involves many families and traditional communities in the region, and finally, it has characteristics that allow us to calibrate and verify the effectiveness of the MuSIASEM methodology in an analysis at the micro-level.

The analysis subject is the life cycle of the Amazon nut and a farmers' cooperative, Coopavam (Vale do Amanhecer Farmers Cooperative), which stands out as the primary agent in the region. Each Amazon nut that circulates in the region either passes through the cooperative or receives its influence. Nuts are collected mainly by indigenous peoples in the region and by farmers who have access to the forest. These nuts are then sold to the Coopavam cooperative or intermediaries; at this point, the cooperative's political strength is emphasized, as the amount paid by the cooperative determines the price per kilogram paid for the Amazon nut in that environment, so the organization is also a regulatory agent in the value chain.

For the data analysis, the recommendations of the MuSIASEM methodology are used, in this way, the variables that make up the semantics of the case study narrative were defined, as well as the production rules and tokens that make up the grammar proposed by the MuSIASEM methodology (Table 1). 
Table 1. Set of semantic category choices, the establishment of production rules and tokens.

\begin{tabular}{|c|c|c|c|}
\hline Variable & Definition & Production Rules & Tokens \\
\hline THA & Total human activity & $\begin{array}{l}\text { Multiply the total number of } \\
\text { hours available in the day, } \\
\text { considering the particularities } \\
\text { between men and women, minus } \\
\text { the time of physiological } \\
\text { overload, by the number of days } \\
\text { available and then multiply by } \\
\text { the number of individuals } \\
\text { covered by the representation; the } \\
\text { sum of hours in HA } \mathrm{HH}_{\mathrm{HH}} \text { e HA. } \\
\text { THA }=\sum \mathrm{h}-\sum \mathrm{HA}_{\mathrm{PO}} \\
\text { or } \\
\text { THA }=\mathrm{HA}_{\mathrm{HH}}+\mathrm{HA}_{\mathrm{PW}}\end{array}$ & $\begin{array}{ll}- & \text { Amount of hours in HAPO } \\
- & \text { Number of days available. } \\
- & \text { Number of individuals. } \\
- & \text { Number of hours of } \mathrm{HA}_{\mathrm{PO}} \\
- & \mathrm{HA}_{\mathrm{HH}} \text { value. } \\
- & \mathrm{HA}_{\mathrm{PW}} \text { value }\end{array}$ \\
\hline $\mathrm{HA}_{\mathrm{HC}}$ & $\begin{array}{l}\text { Total hours of human activity } \\
\text { dedicated to housework. }\end{array}$ & $\begin{array}{l}\text { Multiply the total number of } \\
\text { hours devoted to housework by } \\
\text { the number of days available, } \\
\text { multiplied by the number of } \\
\text { existing individuals. } \\
\text { HA }_{\mathrm{HC}}=\mathrm{h}_{\mathrm{HC}} \times \text { Days } \times \text { Pop }\end{array}$ & $\begin{array}{ll}\text { - } & \text { Average time spent on } \\
\text { domestic services. }\end{array}$ \\
\hline $\mathrm{HA}_{\mathrm{LE}}$ & $\begin{array}{c}\text { Total hours of human activity } \\
\text { dedicated to leisure and } \\
\text { education. }\end{array}$ & $\begin{array}{l}\text { Multiply the total number of } \\
\text { dedicated study } / \text { learning and } \\
\text { leisure hours by the number of } \\
\text { days available, multiplied by the } \\
\text { number of existing individuals. } \\
\text { HA }_{\mathrm{LE}}=\mathrm{h}_{\mathrm{LE}} \times \text { Days } \times \text { Pop }\end{array}$ & $\begin{array}{ll}\text { - } & \text { Average time spent on } \\
\text { leisure and education. } \\
\text { - } \quad \text { Number of days available. } \\
\text { - } \quad \text { Number of individuals. }\end{array}$ \\
\hline $\mathrm{HA}_{\mathrm{PO}}$ & $\begin{array}{c}\text { Total hours of human activity } \\
\text { dedicated to physiological } \\
\text { overload. }\end{array}$ & $\begin{array}{l}\text { Multiply the total number of } \\
\text { hours dedicated to personal care, } \\
\text { sleep, food, etc., by the number of } \\
\text { days available, multiplied by the } \\
\text { number of existing individuals. } \\
\text { HAPO }_{\text {PO }}=\mathrm{h}_{\mathrm{PO}} \times \text { Days } \times \text { Pop }\end{array}$ & $\begin{array}{ll}\text { - } & \text { Average time used in } \\
\text { physiological activities and } \\
\text { personal care. } \\
\text { - } \quad \text { Number of days available. } \\
\text { - } \quad \text { Number of individuals. }\end{array}$ \\
\hline $\mathrm{HA}_{\mathrm{HH}}$ & $\begin{array}{l}\text { Total hours of human activity } \\
\text { dedicated to the household sector. }\end{array}$ & $\begin{array}{c}\text { Add up the total hours spent on } \\
\text { house chores, education, and } \\
\text { leisure. } \\
\qquad \mathrm{HA}_{\mathrm{HH}}=\mathrm{HA}_{\mathrm{HC}}+\mathrm{HA}_{\mathrm{LE}}\end{array}$ & $\begin{array}{ll}- & \mathrm{HA}_{\mathrm{HC}} \text { value. } \\
- & \mathrm{HA}_{\mathrm{LE}} \text { value. }\end{array}$ \\
\hline $\mathrm{HA}_{\mathrm{PW}}$ & $\begin{array}{l}\text { Total hours of human activity } \\
\text { devoted to paid work. }\end{array}$ & $\begin{array}{l}\text { Multiply the total number of } \\
\text { hours devoted to paid work by } \\
\text { the number of days available, } \\
\text { multiplied by the number of } \\
\text { existing individuals; or the hours } \\
\text { allocated to the household sector } \\
\text { are subtracted from the THA. } \\
\text { HA }_{\mathrm{PO}}=\mathrm{h}_{\mathrm{PW}} \times \text { Days } \times \text { Pop } \\
\text { or } \\
\mathrm{HA}_{\mathrm{PW}}=\text { THA }-\mathrm{HA}_{\mathrm{HH}}\end{array}$ & $\begin{array}{ll}\text { - } & \text { Average time spent on paid } \\
\text { activities. } \\
\text { - } & \text { Number of days available. } \\
\text { - } & \text { Number of individuals. } \\
\text { - } & \text { HH (household sector) } \\
\text { - } & \text { value. } \\
\text { THA value. }\end{array}$ \\
\hline
\end{tabular}

Multiply the total number of hours of human activity devoted to the selected sub-compartment by the number of available days multiplied by the number of existing individuals.
Total hours of human activity transferred to a specific sub-compartment.
- $\quad$ Average time used in the sub-compartment.

- Number of days available.

- Number of individuals. 
Table 1. Cont.

\begin{tabular}{|c|c|c|c|}
\hline Variable & Definition & Production Rules & Tokens \\
\hline TET & Total exosomatic throughput. & $\begin{array}{l}\text { Sum the energy of all sources used, in joules, for } \\
\text { the system in the studied period; or the sum of } \\
\qquad \mathrm{ET}_{\mathrm{HH}} \text { e } \mathrm{ET}_{\mathrm{PW}} \text {. } \\
\text { For the conversion of the energy metrics in joules: } \\
1 \mathrm{~kW}=3.6 \cdot 10^{6} \mathrm{~J} \\
1 \mathrm{~kg} \text { of wood }=1.50 \cdot 10^{7} \mathrm{~J} \\
11 \text { diesel oil }=3.64 \cdot 10^{7} \mathrm{~J} \\
1 \mathrm{~kg} \text { de of liquefied petroleum gas }(\mathrm{LPG})= \\
4.70 \cdot 10^{6} \mathrm{~J} \\
\mathrm{TET}=\left(\sum \mathrm{kw} \times \mathrm{V}_{\mathrm{kW}}\right)+\left(\sum \mathrm{m}^{3} / \mathrm{Kg} \times \mathrm{V}_{\mathrm{m} 3}\right)+ \\
\left(\sum 1 \times \mathrm{V}_{\mathrm{l}}\right)+\left(\sum \mathrm{kg} \times \mathrm{V}_{\mathrm{kg}}\right) \\
\text { or } \\
\text { TET }=\mathrm{ET}_{\mathrm{HH}}+\mathrm{ET}_{\mathrm{PW}}\end{array}$ & $\begin{array}{ll}\text { - } & \text { Amount of electric energy } \\
\text { used in the period. } & \text { Conversion value from } \mathrm{kW} \\
\text { of electric energy to joules. } \\
\text { - } \quad \text { Amount of wood used in } \\
\text { the period. } \\
\text { - } \quad \text { Conversion value of } \mathrm{m}^{3} / \mathrm{kg} \\
\text { of wood to joules. } \\
\text { - } \quad \text { Amount of fuel used in the } \\
\text { period. } \\
\text { - Conversion value from } \\
\text { diesel to joules. } \\
\text { Amount of LPG used in the } \\
\text { period. } \\
\text { - Conversion value of } \mathrm{kg} \text { of } \\
\text { - } \quad \text { LTG to joules. }_{\text {HH value. }} \\
\text { ET }\end{array}$ \\
\hline $\mathrm{ET}_{\mathrm{HH}}$ & $\begin{array}{l}\text { Energy throughput to the } \\
\text { household sector. }\end{array}$ & $\begin{array}{l}\text { A sum of energy quantity of all sources in joules } \\
\text { in the household sector in studied period. } \\
\text { For the conversion of the energy metrics in joules: } \\
1 \mathrm{~kW}=3.6 \cdot 10^{6} \mathrm{~J} \\
1 \mathrm{~kg} \text { of wood }=1.50 \cdot 10^{7} \mathrm{~J} \\
11 \text { diesel oil }=3.64 \cdot 10^{7} \mathrm{~J} \\
4.70 \cdot 10^{6} \mathrm{~J} \\
\mathrm{ET}_{\mathrm{HH}}= \\
1 \mathrm{~kg} \text { de of liquefied petroleum gas }(\mathrm{LPG})= \\
\left(\sum_{\mathrm{HH}} \mathrm{kw} \times \mathrm{V}_{\mathrm{kW}}\right)+\left(\sum_{\mathrm{HH}} \mathrm{m}^{3} / \mathrm{Kg} \times \mathrm{V}_{\mathrm{m} 3}\right)+ \\
\left(\sum_{\mathrm{HH}} 1 \times \mathrm{V}_{1}\right)+\left(\sum_{\mathrm{HH}} \mathrm{Kg} \times \mathrm{V}_{\mathrm{Kg}}\right)\end{array}$ & 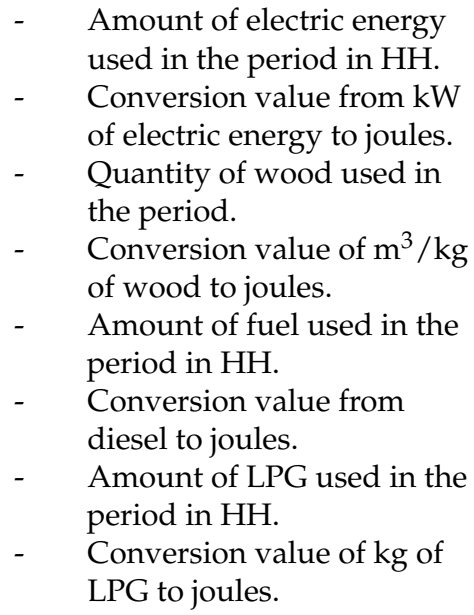 \\
\hline
\end{tabular}

The sum of the energy quantity of all the sources used in joules to produce goods and services in the studied period.

For the conversion of the energy metrics in joules: $1 \mathrm{~kW}=3.6 \cdot 10^{6} \mathrm{~J}$

$1 \mathrm{~kg}$ of $\operatorname{wood}=1.50 \cdot 10^{7} \mathrm{~J}$

$1 \mathrm{l}$ diesel oil $=3.64 \cdot 10^{7} \mathrm{~J}$

$\mathrm{ET}_{\mathrm{PW}} \quad$ Energy throughput to use in services.
Amount of electric energy used in the period in PW.

Conversion value from $\mathrm{kW}$ of electric energy to joules. Amount of firewood used in the period in PW.

- Conversion value of $\mathrm{m}^{3}$ of firewood to joules.

$1 \mathrm{~kg}$ de of liquefied petroleum gas $(\mathrm{LPG})=\quad$ - $\quad$ Amount of fuel used in the period in PW.

- $\quad$ Liter conversion value from diesel to joules.

$$
\begin{gathered}
\left(\sum_{\mathrm{PW}} \mathrm{kw} \times \mathrm{V}_{\mathrm{kw}}\right)+\left(\sum_{\mathrm{PW}} \mathrm{m}^{3} / \mathrm{Kg} \times \mathrm{V}_{\mathrm{m} 3}\right)+ \\
\left(\sum_{\mathrm{PW}} 1 \times \mathrm{V}_{1}\right)+\left(\sum_{\mathrm{PW}} \mathrm{Kg} \times \mathrm{V}_{\mathrm{Kg}}\right)
\end{gathered}
$$

Amount of LPG used in the period in PW.

- $\quad$ Conversion value of $\mathrm{kg}$ of LPG to joules. 
Table 1. Cont.

\begin{tabular}{|c|c|c|c|}
\hline Variable & Definition & Production Rules & Tokens \\
\hline $\mathrm{ET}_{\mathrm{i}}$ & $\begin{array}{l}\text { Energy throughput to a specific } \\
\text { sub-compartment. }\end{array}$ & $\begin{array}{l}\text { Sum of energy of all sources used in } \\
\text { joules in the sub-compartment of } \\
\text { analysis selected in the studied } \\
\text { period. } \\
\text { For the conversion of the energy } \\
\text { metrics in joules: } \\
1 \mathrm{~kW}=3.6 \cdot 10^{6} \mathrm{~J} \\
1 \mathrm{~kg} \text { of wood }=1.50 \cdot 10^{7} \mathrm{~J} \\
11 \text { diesel oil }=3.64 \cdot 10^{7} \mathrm{~J} \\
1 \mathrm{~kg} \text { de of liquefied petroleum gas } \\
(\mathrm{LPG})=4.70 \cdot 10^{6} \mathrm{~J} \\
\mathrm{ET}_{\mathrm{i}}=\left(\sum_{\mathrm{i}} \mathrm{kw} \times \mathrm{V}_{\mathrm{KW}}\right)+ \\
\left(\sum_{\mathrm{i}} \mathrm{m}^{3} / \mathrm{Kg} \times \mathrm{V}_{\mathrm{m} 3}\right)+\left(\sum_{\mathrm{i}} 1 \times \mathrm{V}_{1}\right)+ \\
\left(\sum_{\mathrm{i}} \mathrm{Kg} \times \mathrm{V}_{\mathrm{Kg}}\right)\end{array}$ & $\begin{array}{l}\text { - Amount of electric energy } \\
\text { used in the period in the } \\
\text { sub-compartment analyzed. } \\
\text { Conversion value from kW } \\
\text { of electric energy to joules. } \\
\text { - Amount of firewood used in } \\
\text { the period in the } \\
\text { sub-compartment analyzed. } \\
\text { Conversion value of } \mathrm{m}^{3} \text { of } \\
\text { firewood to joules. } \\
\text { Amount of fuel used in the } \\
\text { period in the } \\
\text { sub-compartment analyzed. } \\
\text { Conversion value from } \\
\text { diesel to the joule. } \\
\text { Amount of LPG used in the } \\
\text { period in the } \\
\text { sub-compartment analyzed. } \\
\text { Conversion value of kg of } \\
\text { LPG to joules. }\end{array}$ \\
\hline
\end{tabular}

The sum of all the wealth generated in the system. The collection sector adds nut sales value and the sum of all the products sold by the cooperative in the sector PS:

Total values circulated in metabolism.

$$
\mathrm{GDP}=
$$

$\sum \$$ collect $+\sum$ Revenues $+\sum$ Others where:

$\mathrm{PP}=$ Purchase price

$\$$ collect $\left.=\mathrm{PP} \times \sum \mathrm{Kg}\right)$
- $\quad$ Amount of nuts delivered to the cooperative.

- $\quad$ Value paid for $\mathrm{kg}$ of nut.

- $\quad$ Retire sale with sale of products.
Sum of all the wealth generated in a sub-compartment.

$\mathrm{GDP}_{\mathrm{i}}=\sum$ Revenues in the sub compartment.

Source: Prepared by the author based on Giampietro and Mayumi [27], Giampietro and Mayumi [28], Giampietro and Gamboa [67], Giampietro and Mayumi [68].

After executing the production rule, it is expected to produce exosomatic metabolic rates, energy intensity, work efficiency, and productivity (Table 2). 
Table 2. Intensive variables used in the study.

\begin{tabular}{|c|c|}
\hline Variable & Calculation \\
\hline EMR $_{S A}$ & $\begin{array}{c}\text { Total exosomatic energy throughput/total human activity } \\
\text { EMR }_{\mathrm{SA}}=(\mathrm{TET} / \mathrm{THA})\end{array}$ \\
\hline $\mathrm{EMR}_{\mathrm{i}}$ & $\begin{array}{l}\text { Energy throughput to the sector/human activity in the sector. } \mathrm{PW} ; \mathrm{HH} ; \ldots \\
\qquad \mathrm{EMR}_{\mathrm{i}}=\left(\mathrm{ET}_{\mathrm{i}} / \mathrm{HA}_{\mathrm{i}}\right)\end{array}$ \\
\hline $\mathrm{PR}_{\mathrm{SA}}$ & $\begin{array}{l}\text { Total produced } / \text { total human activity } \\
\mathrm{PR}_{\mathrm{SA}}=(\mathrm{PT} / \mathrm{THA})\end{array}$ \\
\hline $\mathrm{PR}_{\mathrm{i}}$ & $\begin{array}{l}\text { Total produced in sector } / \text { human activity in sector } \\
\qquad \mathrm{PR}_{\mathrm{i}}=\left(\mathrm{PT}_{\mathrm{i}} / \mathrm{HA}_{\mathrm{i}}\right)\end{array}$ \\
\hline $\mathrm{ELP}_{\mathrm{SA}}$ & $\begin{array}{l}\text { GDP } / \text { total human activity. } \\
\mathrm{ELP}_{\mathrm{SA}}=(\mathrm{GDP} / \mathrm{THA})\end{array}$ \\
\hline $\mathrm{LP}_{\mathrm{i}}$ & $\mathrm{GDP}$ in sector/human activity in sector $\left(\mathrm{GDP}_{\mathrm{i}} / \mathrm{HA}_{\mathrm{i}}\right)$ \\
\hline $\mathrm{El}_{\mathrm{SA}}$ & $\begin{array}{l}\text { Total exosomatic energy throughput/PIB. } \\
\qquad \mathrm{El}_{\mathrm{SA}}=(\mathrm{TET} / \mathrm{GDP})\end{array}$ \\
\hline $\mathrm{El}_{\mathrm{i}}$ & $\begin{array}{l}\text { Energy throughput to the sector } / \mathrm{GDP} \text { in sector. } \\
\qquad \mathrm{El}_{\mathrm{i}}=\left(\mathrm{ET}_{\mathrm{i}} / \mathrm{GDP}_{\mathrm{i}}\right)\end{array}$ \\
\hline $\mathrm{EE}_{\mathrm{SA}}$ & GDP/total exosomatic energy throughput \\
\hline $\mathrm{EE}_{\mathrm{i}}$ & $\begin{array}{l}\text { GDP in sector/energy throughput to the sector } \\
\qquad E_{\mathrm{i}}=\mathrm{TET} / \mathrm{HA}_{\mathrm{PS}}\end{array}$ \\
\hline SEH & $\begin{array}{c}\text { Strength of exosomatic hypercycle } \\
\text { SEH = TET } / \mathrm{HA}_{\mathrm{PS}}\end{array}$ \\
\hline BEP & $\begin{array}{l}\text { Bio-economic pressure } \\
\text { BEP = TET } / \mathrm{HA}_{\mathrm{PS}}\end{array}$ \\
\hline
\end{tabular}

Source: Prepared by the author based on Giampietro and Mayumi [48,49,57], Giampietro and Gamboa [56].

Coopavam is located in the last untouched region of MT (Figure 1) [17]. The first step in the research design of a case study is developing the conceptual framework that will underlie the research and explain the main aspects of the study [66]. The region was chosen because of the researchers' interest and for the possibility of data triangulation; for this scope, semi-structured interviews were carried out to understand how the area residents use their time (physiological overload, housework, education, and leisure). The results were validated with the United Nations Development Program delegate, who also acts as a consultant for Coopavam [64].

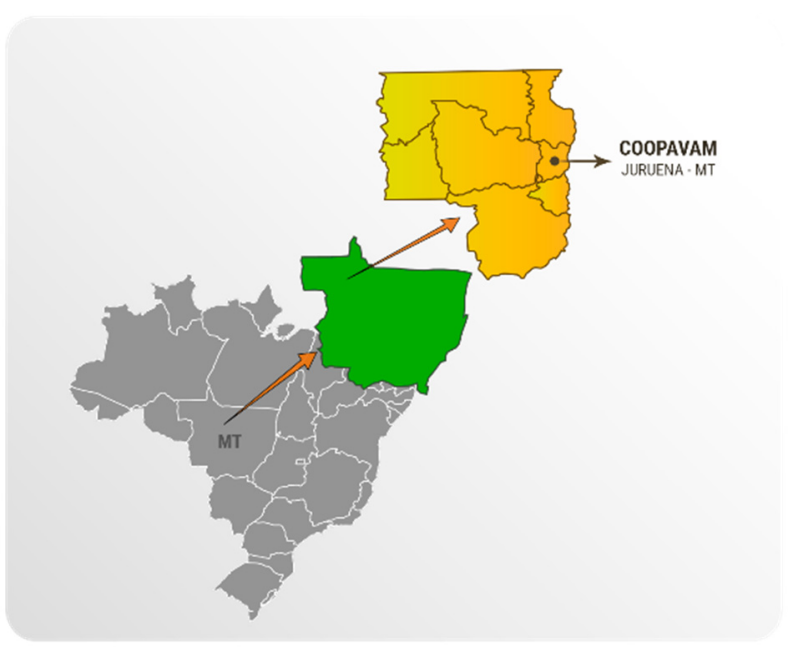

Figure 1. Case study location.

Data collection was performed on location (Figure 1). A visit was made to the Coopavam plant, where the necessary documents for the research were collected, such as inventory worksheets, total number of nuts received by the cooperative, rotary dryer controls, balance sheet, income statement for the year, the cooperative list with names of the members, list of responsible collectors in indigenous lands and settlements, energy 
bills, etc. In addition, data were collected from observations made on the site that were recorded in the field notebook [70].

We conducted two interviews. The first one with Edina Tereza Roque, who lives in the settlement, to understand the routine and lifestyle of residents. The second one was with Paulo César Nunes, who is linked to ADERJUR (Juruena's Rural Development Association) and who has a long experience with the Amazon nut issue in the region, since his work began in the 1990s to learn about the dynamics of the nut production chain, the cultural habits of the settlers and indigenous people, and the resources used in the collection and nut processing. The authors performed this step to validate the narratives constructed in the MuSIASEM method.

\section{Results}

The dataset used for this document reveals that the Amazon nut life cycle is quite complex. Settlers collect theAmazon nuts in a common area belonging to them, and the indigenous people of the forest collect the Amazon nuts in the indigenous reserve. Some landowners allow their Amazon nut trees to be harvested or sign a partnership contract with the indigenous people of the settled communities. Our theoretical analysis considers the cycle of the nut until the sale of the cooperative's products, usingthe MuSIASEM methodology.

For the construction of funds and narrative flows, the production rules established for the system were executed based on the tokens obtained in the interviews and researched documents.

From the establishment, the flows and funds narratives were chosen and applied to the desired intensive variables for the completeness of the case study. We built the multilevel analysis matrix in three levels (Figure 2), where the compartments can be viewed to understand the analyses.

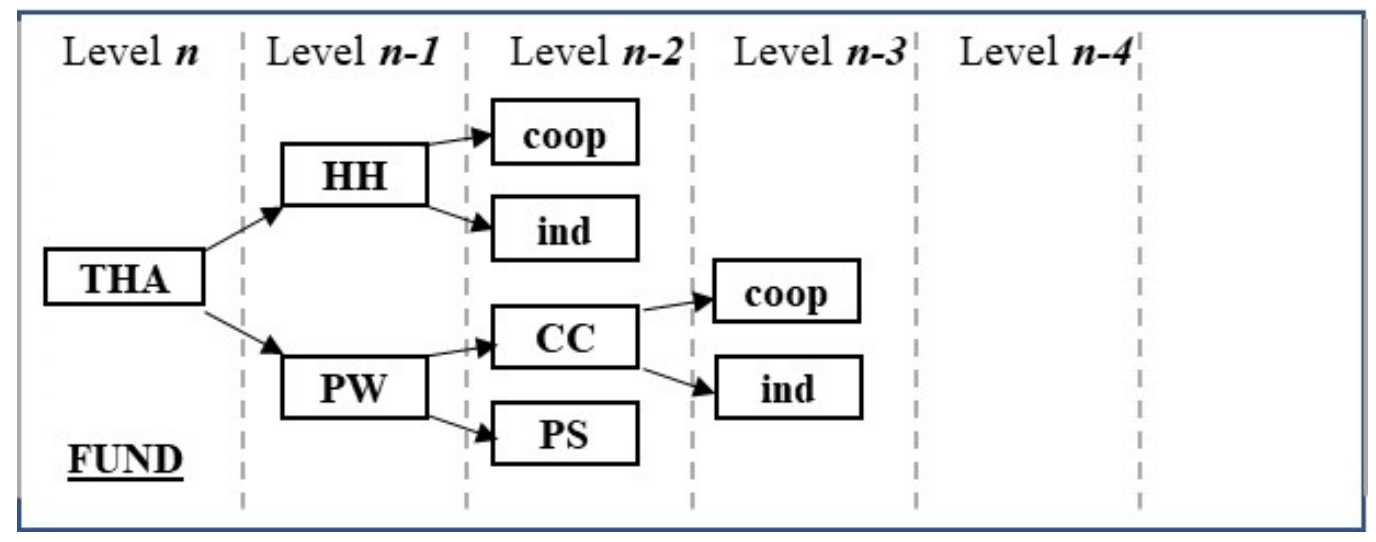

Figure 2. Structure of the proposed multi-level analysis matrix. Note: THA (total human activity), HH (household sector); PW (paid activity); coop (activities carried out by Coopavam); ind (activities allocated to indigenous peoples). Level $n$ and $n-1$, adapted from Giampietro, Mayumi, and Ramos-Martin [57], and Level $n-2$ and $n-3$, adapted from Maldonado, Panhoca, and Allievi [64].

At level $n-1$, two subdivisions are allocated, the consumer sector $(\mathrm{HH})$ and the paid activity sector (PW); up to this point, the structure follows the theoretical model recommended by Giampietro and Mayumi [57]. It establishes that level $n$ represents the entire production chain studied, thus being the compartment that gathers the total resource to be analyzed for the entire system. For levels $n-2$ and $n-3$, the names of the categories of the sub-compartments are appropriate to the context researched, with ind being the resources allocated to indigenous peoples, and coop, those that are directed to the activities carried out by Coopavam, appearing on both levels, both for activities in $\mathrm{HH}$ and for activities within PW. Still, at level $n-2$, there are breakdowns of the PW sector, PS, the 
Coopavam manufacturing processes of new products, and CC, the collection and work of harvesting nuts in the forest.

The human activity fund contains, as the name suggests, all the time of human activity, which does not include time spend on physiological overload (HAPO), for activities maintaining 'metabolism', whether in domestic service, leisure or education, that do not generate physical products that will leave this metabolism, as well as the activities that will do so, which are treated as paid work (Table 3).

Table 3. Total human activity of the cooperative in 2016.

\begin{tabular}{ccccccc}
\hline Sectors HA & Week & $\begin{array}{c}\text { Women } \\
\text { Month }\end{array}$ & Year & Week & $\begin{array}{c}\text { Men } \\
\text { Month }\end{array}$ & Year \\
\hline HAPO & 2604 & 11,160 & 135,780 & 2173.5 & 9444.4 & $113,332.5$ \\
HAPW & 1364 & 7254 & 87,048 & 1188 & 6318 & 75,816 \\
HAHH (HC + LE) & 934.6 & 4061 & 48,732 & 908.5 & 3947.6 & $47,371.5$ \\
HAHC & 418.5 & 1818.5 & $21,821.8$ & 135.0 & 586.6 & 7039.3 \\
HALE & 516.1 & 2242.5 & $26,910.2$ & 773.5 & 3361.0 & $40,332.2$ \\
\hline
\end{tabular}

Source: Research data.

We verified the metabolism's sources and energy and took the values from analyzing documents and information from the interviews. We found that the energy utilization (Table 4) in the metabolism happens through the consumption of firewood, electric energy, vehicular fuels, and liquefied petroleum gas (LPG), also known as cooking gas.

Table 4. Energy consumption in metabolism in 2016.

\begin{tabular}{ccc}
\hline Source & Consumption & ${\text { Consumption }(G))^{\mathbf{a}}}^{\mathbf{a}^{2}}$ \\
\hline Electricity & $55,035 \mathrm{kWh}$ & 198.126 \\
Vehicle fuels & $833,333 \mathrm{~L}$ & 30.33 \\
Liquefied petroleum gas & $3198 \mathrm{Kg}$ & 150.31 \\
Firewood & $1155 \mathrm{~m}^{3}$ & 12.375 \\
\hline TOTAL & - & 12.7538 \\
\hline
\end{tabular}

Source: Research data. ${ }^{a}$ Gigajoules. Conversion rate: $1 \mathrm{Kwh}=3.6 \cdot 10^{6} \mathrm{~J}(76.77)$.

Regarding the extraction of Brazil nuts from the forest, in 2016, due to the forest's low productivity, the total circulated in the narrative studied was 91 tons of nuts (Table 5). However, according to E2 and E1, the cooperative had already processed 300 tons of Amazon nuts at a good harvest time, forcing it to operate at times in a three-shift regime, and it was not possible to increase this productive capacity due to problems with working capital.

Table 5. Amazon nut flow in the Mato Grosso's northwest in 2016.

\begin{tabular}{cc}
\hline Source & Amount (kg) \\
\hline Vale do Amanhecer & 19,095 \\
Passapkareey a & 41,956 \\
Kawaiwete_Kaiabi & 15,727 \\
Munduruku & 9535 \\
Acaim b & 4687 \\
\hline Total & 91,000
\end{tabular}

Source: Research data. ${ }^{a}$ An association of the Cinta Larga Indians (Pandereej) villages near Aripuanã-MT that centralizes these villages commercialization. ${ }^{b}$ Mayrobi indigenous village community association, the organization that concentrates the commercialization of the production of the Apiaká Indians of the Mayrobi village.

The income compartment begins with the extraction of Amazon nuts from the forest. In 2016, Coopavam paid an average of BRL3.54/ $\mathrm{kg}$ of collected nuts, which can not be taken as cost price, since the cooperative, excluding nuts delivered by the settlers, still has to cover the cost of fuel to get this product, as well as maintenance and depreciation of 
trucks. In the year studied, Coopavam paid for the 91 tons of Amazon nuts acquired about BRL322,200.00.

We also consider for this fund the amounts referring to Coopavam. In 2016, revenues were BRL960,000.00 from the sale of products from Amazon nuts, dehydrated whole nuts vacuum-packed (best seller), then cereal bars, nut oil, and, finally, the Amazon nut flour. Flour is a by-product of oil extraction, and its production reflects the low oil productivity.

The first relationship studied was between the proportion of human activity and energy used, considered by MuSIASEM as the background and flow, respectively, the most important narrative (Figure 3). After establishing the flows and backgrounds of the narrative, it was then decided to produce the intensive variables. That is the application of the multi-level matrix built for this micronarrative.

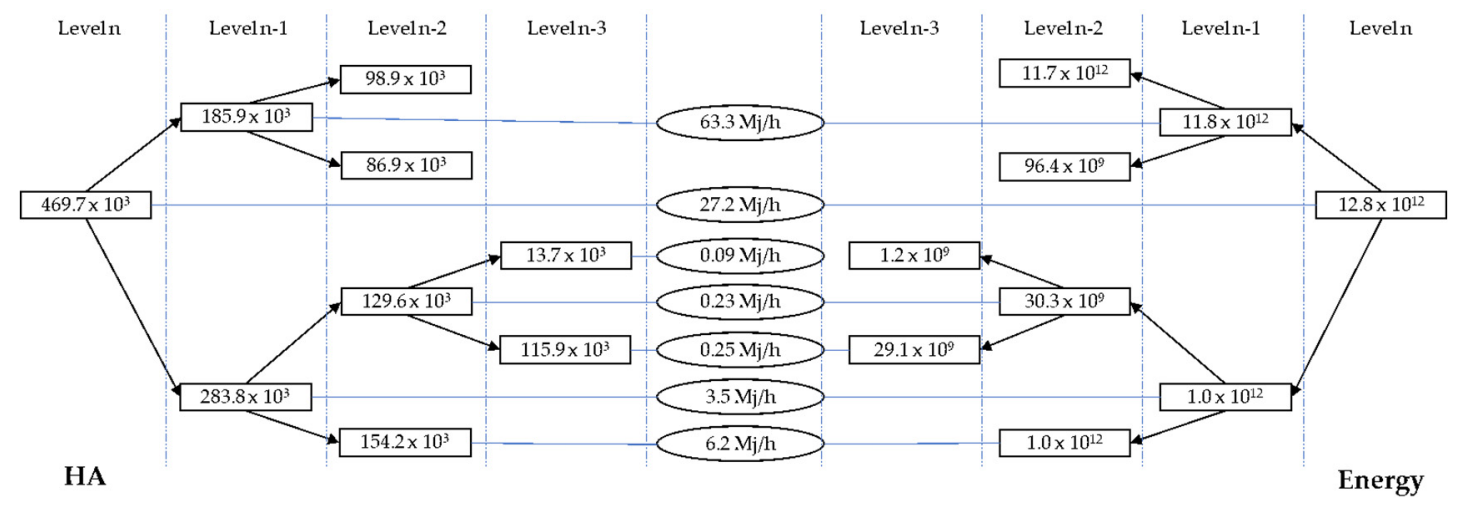

Figure 3. Analysis matrix of human activity versus energy of production. Note: " $\mathrm{e}$ " is the scientific notation for a base 10 exponent, e.g., 1e3 = $10^{3}$ (ćurčić-blake).

The narrative presented significant indicators for 2016, such as an EMRSA of $27 \mathrm{MJ} / \mathrm{h}$ concerning that established by Giampietro and Gamboa [56], similar to the metabolic rate of developed countries (Spain in 1996 had an EMRSA = 20 MJ/h). However, it is essential to note that Giampietro and Gamboa [56] refer to an EMR of 20 years ago. In South America, Recalde and Ramos-Martin [71] found an EMRSA of 11.47 MJ/h in Argentina for 2007.

Another indication of this observation is corroborated when comparing the metabolic rhythms of the consumer sector $(\mathrm{HH})$ and the productive sector $(\mathrm{PW})$, where the primary demand for energy is made by the consumer sector (Figure 4).

Another indicator demonstrated by this rate is the low environmental impact of the activity, since it demands little external energy, especially in the collection period that demands $0.234 \mathrm{MJ} / \mathrm{h}$ for its realization, where the indigenous communities demand $0.25 \mathrm{MJ} / \mathrm{h}$ due to the need for carrying of the nuts and more people involved in this process. In comparison, processing requires $6.22 \mathrm{MJ} / \mathrm{h}$, which could perhaps be reduced by replacing wood in the production process.

Subsequently, the relationship between production and work is analyzed. The indicators have relatively low values justified by the nature of the activity. Generally, the collection work yields about $702 \mathrm{~g}$ of Amazon nuts per hour of human activity. At this point, it is interesting to note that indigenous communities, even with a more significant number of people, collect about $44 \%$ fewer nuts than the cooperative workers, who collect nuts at work in the Vale do Amanhecer settlement.

In terms of income, the relationship with human activity was also established. This analysis suggests, in particular, the amount of added value for each hour of activity that is best viewed in the analysis matrix (Figure 5). 


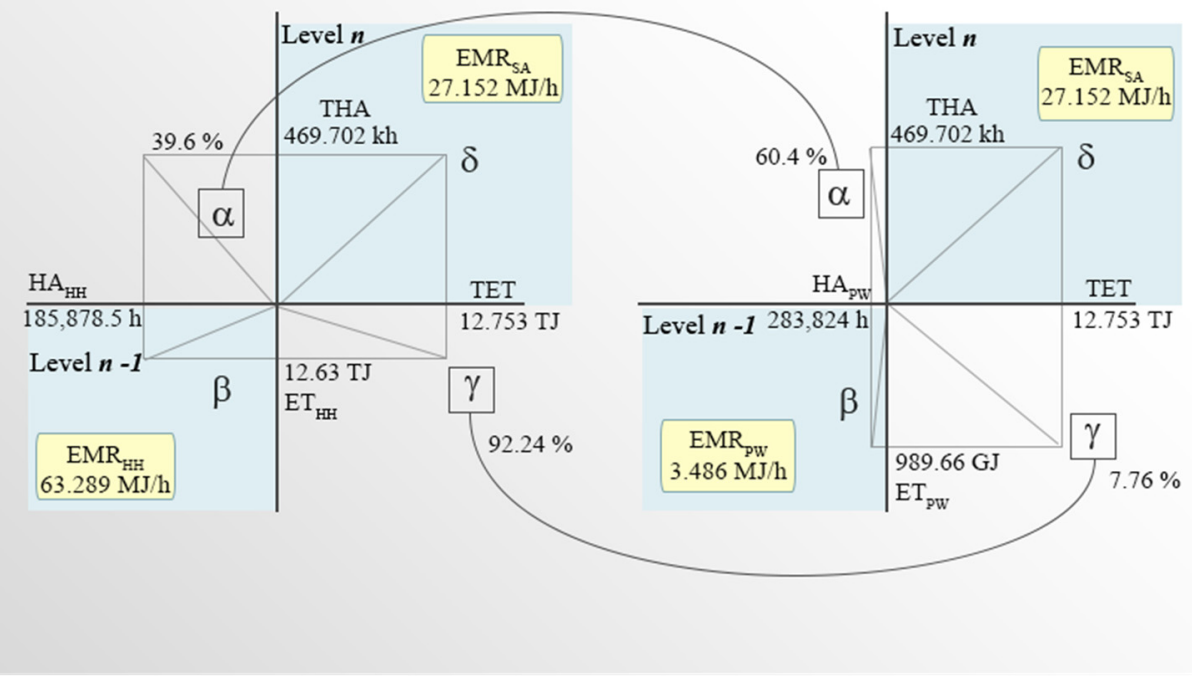

Figure 4. Composition of energy versus human activity energy of the production chain. Note: the $\alpha$ represents the consumption of funds in the household and paid work sector. Moreover, $\gamma$ is the consumption of the flow in the same sector.

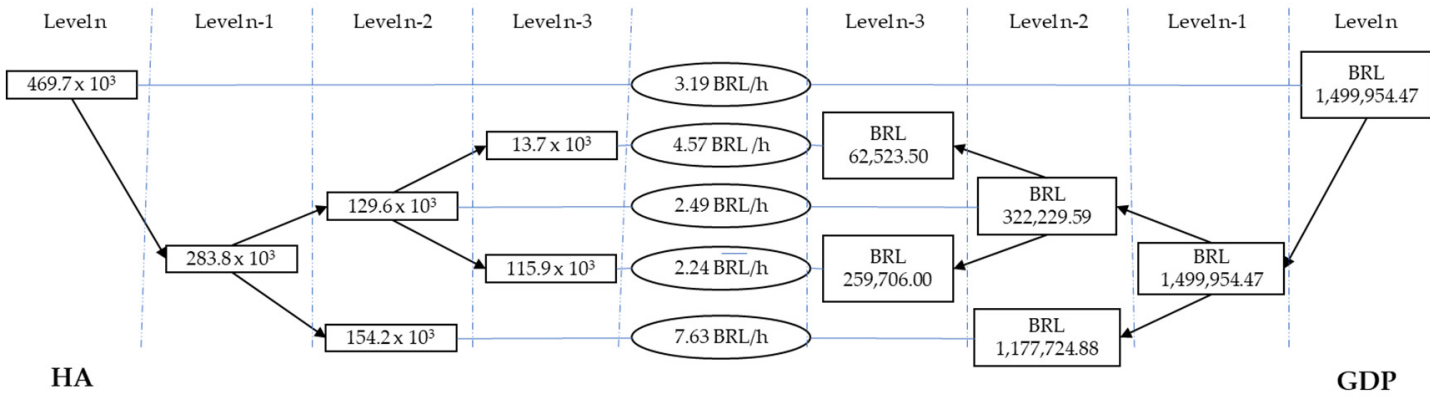

Figure 5. Analysis matrix of human activity versus income in production. Note: $\mathrm{R} \$$ the official Brazilian currency since 1994 called "real" in Portuguese.

The results show average labor productivity in the Amazon nut production chain, which is slightly lower than expected when comparing this value with that of a person earning a minimum wage in 2016 [72] and working the same amount of hours, BRL3.76/h (reals per hour) of human activity in paid work.

When observing the value of ELPcc(cp) (BRL4.57), which refers to the collective work of the cooperative, this worker received $21 \%$ more than a typical worker who received a minimum wage in the analyzed year, coming close to the average income of the Brazilian who lived in the MT this year, BRL4.87 [73]. What encourages the maintenance of these activities that accounted for $78.52 \%$ of all income generated in the system (Figure 6). 


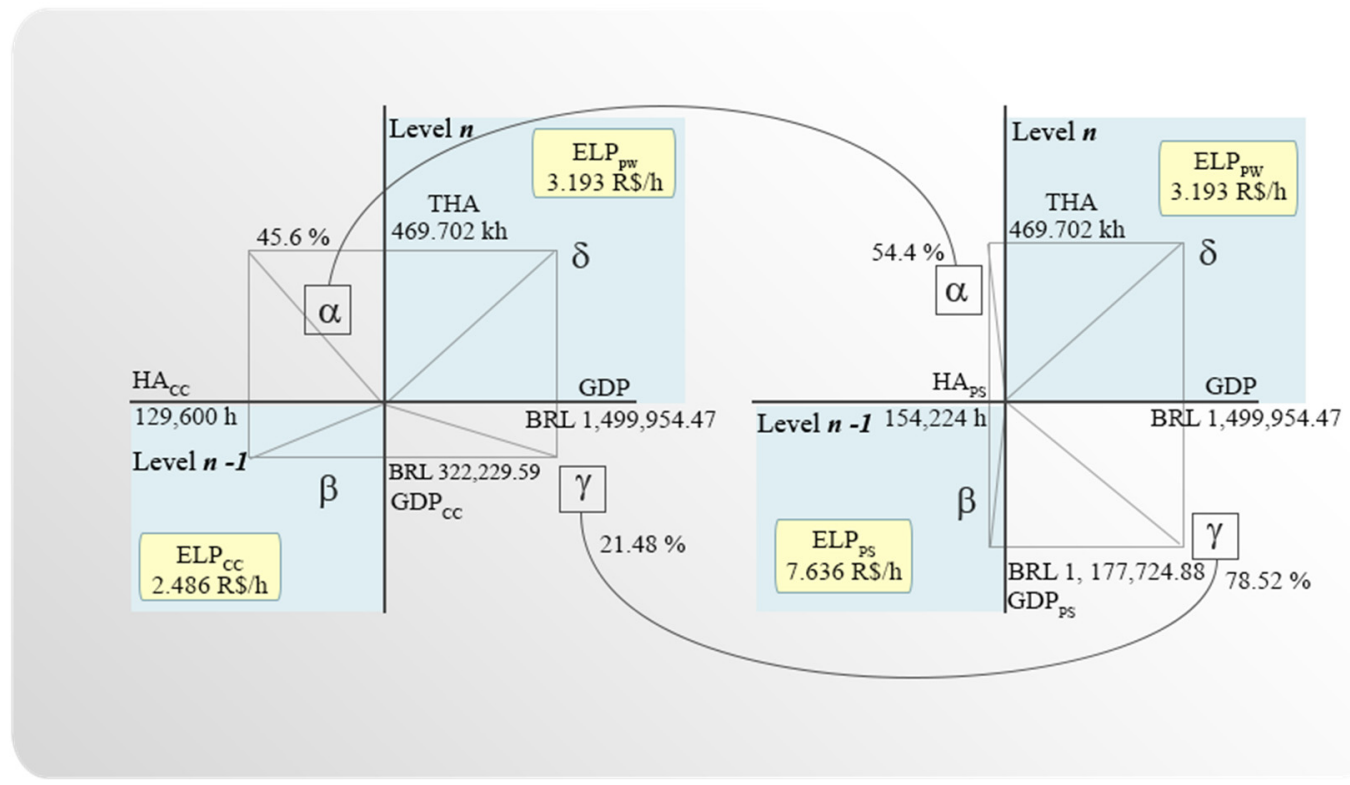

Figure 6. Composition chart of income versus human activity in the production chain. Note: $\alpha$ represents the consumption of the fund in the collection and productive work sector. Moreover, $\gamma$ is the consumption of the flow in the same sector.

Finally, energy intensity rates demonstrate low energy efficiency in the Amazon nut production chain as a whole (EESA $=$ BRL0.12/MJ or reals per megajoule), similar to the value found by Recalde and Ramos-Martin [71] for the agricultural sector of Argentina, and that is a low value. It does not include the $\mathrm{HH}$ sector, which is high consumption; the narrative analysis will focus on the PW sector. The activity that presents the best relationship between energy consumption and value aggregation is in the collection phase, where each megajoule of energy consumed produced BRL10.62 for the system. This value is even more significant if we analyze at the $n-3$ level the harvesting activity of the farmers of the Vale do Amanhecer settlement, which was far superior to any other activity of the narrative; the processing step, however, was well below expectations.

\section{Discussion}

The case study research has certain limitations [74]. The research has limitations due to its exploratory nature and the limited number of investigated cases. A lack of representativeness and generalizability limits the case studies. However, as Molina-Maturano and Bucher [75] do, we assume that formal generalization is overvalued in the study of environmental affairs and that context-dependent knowledge is more valuable in this realm than general knowledge. On the other hand, there is the argument that case studies are particularly suitable for explorative research, and can also be used to test hypotheses, concepts, and theories and build them or develop them [76].

Establishing the narrative through the multi-level matrix presented in Figure 2 is essential for NTFPs' extractive chains. The matrix allows to target on other micronarratives in the Amazonian context such asthe exploitation of rubber, Buriti (Mauritia flexuosa), which may include more significant extensions of activities such as fiber processing, Copaíba oil (Copaifera langsdorffii), and others.

For this study, it has not been possible to establish adequate benchmarks since the works published on the theme used whole country narratives, except for that of Matthews and Blackstock [77], who analyzed a smaller area in Scotland; however, the use of analysis via MuSIASEM has been restricted to land use and the PW fund. The first analysis matrix used the totals related to the human activity fund (HA) and the energy flow (ET) previously established from the collected data.

Regarding the background of human activity, the cooperative has 58 members, 31 women and 27 men, who carry out activities in the production line of the Cooopavam's plant, and 
some of these are also involved in the collection during the harvest period that occurs between December and May of each year.

In the paid work sector, we used the time in which the cooperative in general is engaged in activities in the production line, in the cooperative's factory. This corresponds to a working week similar to that of the common urban worker in Brazil, of $8 \mathrm{~h}$ a day, Monday to Friday and on a Saturday morning (English week).

It is important to note that we determined the total hours used in the consumer sector, and this was the average time spent on household chores, education, and leisure. Domestic tasks including all work involving the maintenance and cleaning of the house in rural dwellings, care of livestock, milk extraction for consumption, etc., were considered. We identified these tasks, and it was necessary to divide them between the women and men who participated in the 'metabolism'. Since the division of tasks and the nuances of gender are still quite present in this context, women spent on average $13.5 \mathrm{~h}$ a week to perform these tasks, while men, in turn, were engaged for $5 \mathrm{~h}$ week in their household chores. This demonstrates that at least in rural contexts in the interior of the country, a double shift for women is a fact that is still present [78].

In establishing the flow of energy, the value of the narrative expressed for this activity may have been increased due to energy consumption such as firewood burning, which has high values related to the workforce. Firewood is sourced in the forest from dead trees but must be collected and transported. Biomass was characterized as the most expressive, accounting for $97 \%$ of all energetic transference in the studied metabolism. As previously stated, it is justified because it is a free energy source and accessible. This last fact must be considered since cleaner energies, such as LPG, are expensive in the region, due to distances and transport conditions for this item. The discussion brings up the interference of government decisions (such as incentives, paving roads, etc.) in the economic-environmental choices of individuals of a given metabolism.

In a preliminary analysis (Figure 3), this would confirm a state of development in which people are more likely to be involved in leisure activities, and education. However, this was not confirmed when we checked the distribution of HA for the narrative, where HAHC + LE essentially consisted of the number of hours devoted to household chores $(115,801 \mathrm{~h})$. Another sign, which does not apply to this narrative, is the demographic situation of the studied population because the high energy demand in $\mathrm{HH}$ suggests an elderly population. However, the average age of the cooperative was 41 years, while it was not possible to access this information from the indigenous population. Additionally, the comparison with a state of full development is not confirmed since $60 \%$ of human activity is dedicated to working.

Still in this sense, the narrative becomes unique because, despite having an EMRSA and a high EMRHH, the metabolic rate for the productive sector is low, with a rate of $3.48 \mathrm{MJ} / \mathrm{h}$, which was not analyzed at the country level. For example, the authors point out that in China, considered a developing country, in 1999, the PW sector demanded $15.81 \mathrm{MJ} / \mathrm{h}$, while in Argentina, it was $82.96 \mathrm{MJ} / \mathrm{h}$. However, it is believed that this value reflects the low technology used in the processes, especially as it is an extractive activity, and during processing, machines are in a higher position of production aid [56].

Labor and income (Figure 6) data may reflect the time taken by indigenous communities to reach nut trees and transport the Amazon nuts collected through the forest to the delivery point. In the processing of the nuts (product) each hour of work, about $600 \mathrm{~g}$ of Amazon nuts are processed, because the processing is manual in most cases, as well as including the time spent in drying the batches of Amazon nuts that may require more than $24 \mathrm{~h}$ in the rotary dryer.

However, this value may be influenced by the collective work of the indigenous communities, which registered the lowest average value of BRL2.24/h, which in turn places a low value on the collection work. However, the low value presented for collection does not suggest the exploitation of this group. 
If we compare the average amount paid per kilo of Amazon nuts to the indigenous people, it is about $8 \%$ higher than that paid to the cooperative that performs the same work (BRL3.55/ kg for the Indian communities and BRL3.27/ kg for Vale do Amanhecer workers). The justification for this low value is in the lower productivity of these communities, which can be explained, as previously mentioned, by the time spent in commuting, and it can also suggest a strong relationship with intermediaries, which would indicate greater productivity for this group; however, these values could not be determined.

The analysis confirms the potential for income generation in nut processing (Figure 6), since using the same labor potential, this sector produces almost $80 \%$ of all the money circulating in the system. If we compare ELP rates for 2016, the processing sector added triple the value of the primary collection activity.

Finally, on the energy intensity rates analysis, even if we consider the highest ELP for the level of the collection (CCcp), the processing of the Amazon nut in manufactured products accounts for about $40 \%$ more value than the commercialization of the nut in nature. Some alternatives should be considered for processing when it comes to the energetic intensity of this narrative.

The verified EEPS indicates low energy efficiency in the manufacturing process. In 2016 each megajoule used in the processing of Amazon nuts generated only BRL1.23. This low aggregation of value can be explained, once again, by the use of primary energies from biomass burning. That is confirmed by excluding from the calculation of ETPS the joule value for the $80 \mathrm{~m}^{3}$ of firewood used in 2016 for the drying process of the nut, presenting an eight times higher rate of energy efficiency. However, this value should be viewed with caution because the value of the excluded energy must be replaced by another more sustainable energy that meets the needs of the process.

As research and method limitations, the authors list some points. First of all, the impossibility of determining the size of the Amazon nut areas used by indigenous communities prevented forming a land-use fund, which could produce interesting intensive variables to be observed. It is also important to note that it was impossible to perform the impredicative loop analysis and establish the bioeconomic pressure (BEP) and exosomatic hypercycle (SEH) indicators. Due to the analyzed system, the methodology developed was based on analyses of whole countries. In this case, since it is a specific value chain, it is impossible to determine the HA values in PW used for HH supply. Furthermore, due to the specificity of the case, it was not possible to establish adequate benchmarks at the level of analysis proposed, and it is necessary to carry out more studies in extractive chains to obtain a better overview of the actual situation of the researched context.

\section{Conclusions}

This study aimed to analyze the eco-socio-environmental metabolism of the Amazon nut production chain in the northwest of the State of Mato Grosso through the MuSIASEM approach. The study was based on the sustainability perspective of understanding human activities as social metabolisms [26]. To this end, it was chosen as a tool for analyzing the metabolism of the Amazon nut production chain, MuSIASEM [79].

However, the study demonstrates that the metabolism presented in this narrative raises some challenges, such as the need to stimulate the use of clean energy since individuals have free access to inefficient sources (as shown in Figure 4). From the social point of view, there is also a need to develop policies regarding education and leisure in the region.

It is considered that the metabolism of the production chain of the Amazon nut in the northwest of MT presents a state of equilibrium. However, some problems must be observed as the influence of external agents, especially intermediaries, that need to be studied to understand their role and scope in metabolism. The use of inefficient energies has also been a frequent problem influencing the values of some indicators.

The extractive activity of NTFPs has an essential role in generating income for local indigenous populations and the environmental preservation of the Amazon biome. The analyzed metabolism can be characterized as a complex environment where the activity 
involves social, cultural, and economic factors for the inhabitants of this region. The influence of the intermediaries and their presence in the global nut trade has been verified. Indigenous people and intermediaries are seen as actors in the cycle; although not much is known about the role of these actors, they should be considered a suggestion for future studies. The main actors who have the decision-making power in supply chains are the companies operating in NTFP businesses [80].

The study in this way highlights the importance of research on micronarratives since NTFPs are consumed worldwide, especially in developed countries. However, information on the balance of this activity is little explored. To insist on a discourse of preservation of the Amazon based on statistical evidence without considering that it is an extensive metabolism composed of several micronarratives is not effective. Considering the components of these narratives, which are the main actors in the destruction/preservation of the forest and promoting activities that promote a metabolic balance, is perhaps a more attractive way to preserve the Amazon.

Finally, this study is concluded by suggesting for future research the application of the MuSIASEM methodology in other micronarratives, especially extractive chains, to establish benchmarks more appropriate to this level of analysis. It is also suggested to carry out a study with scenario projections for subsequent crops. It could provide the social actors involved with information pertinent to their future planning, besides the importance of the production of an intensive variable, if there is an opportunity to establish a land-use fund, so that it is possible to verify the extractive process as a whole and can establish relations of productivity per hectare. Studies are needed on relationships, and middleman performance in the region, since these components of metabolism have a significant influence on the functioning of the system as a whole and the social influence they represent above all in the indigenous communities.

Author Contributions: Conceptualization, F.A. and L.P.; data curation, T.V.M.; formal analysis, T.V.M. and F.A.; funding acquisition, L.P.; investigation, T.V.M.; methodology, T.V.M., F.A. and L.P.; project administration, F.A. and L.P.; resources, L.P.; software, T.V.M.; supervision, T.V.M., F.A. and L.P.; validation, T.V.M., F.A. and L.P.; visualization, T.V.M. and F.A.; writing—original draft, T.V.M. and F.A.; writing-review and editing, T.V.M., F.A. and L.P. All authors have read and agreed to the published version of the manuscript.

Funding: CAPES: Coordination for Improvement of Higher Education Personnel and CNPQ, National Counsel of Technological and Scientific Development (process 402940/2016-4) supported Luiz Panhoca.

Institutional Review Board Statement: We conducted this research in accordance with the directives of the Declaration of Helsinki. The Board of the Graduate Program in Accounting and two qualification and certification boards at the Federal University of Paraná (UFPR) approved this research.

Informed Consent Statement: Informed consent was obtained from all subjects involved in the study.

Data Availability Statement: All data and information regarding this research are available upon request.

Acknowledgments: We want to express our sincere gratitude to all the editors and reviewers. The authors are grateful to several colleagues for their contributions: Giovanni Dotelli, Jyrki Luukkanen, Mario Giampietro, and the people of Coopavam and residents of Vale do Amanhecer for their willingness to receive us and provide the data for this study.

Conflicts of Interest: The authors declare no conflict of interest.

\section{References}

1. Schaafsma, M.; Morse-Jones, S.; Posen, P.; Swetnam, R.D.; Balmford, A.; Bateman, I.J.; Burgess, N.D.; Chamshama, S.A.O.; Fisher, B.; Green, R.E.; et al. Towards transferable functions for extraction of Non-timber Forest Products: A case study on charcoal production in Tanzania. Ecol. Econ. 2012, 80, 48-62. [CrossRef]

2. Cvitanovic, C.; McDonald, J.; Hobday, A.J. From science to action: Principles for undertaking environmental research that enables knowledge exchange and evidence-based decision-making. J. Environ. Manag. 2016, 183, 864-874. [CrossRef] 
3. Ripple, W.J.; Wolf, C.; Newsome, T.M.; Galetti, M.; Alamgir, M.; Crist, E. World Scientists' Warning to Humanity: A Second Notice. BioScience 2017, 12, 1026-1028. [CrossRef]

4. UCS Union of Concerned Scientists. Science for a Healthy Planet and Safer World; UCS Union of Concerned Scientists: Cambridge, MA, USA, 2017.

5. UCS Union of Concerned Scientists. World Scientists' Warning to Humanity; UCS Union of Concerned Scientists: Cambridge, MA, USA, 1997.

6. Blignauta, J.; Aronson, J. Developing a restoration narrative: A pathway towards system-wide healing and a restorative culture. Ecol. Econ. 2020, 168, 1-9. [CrossRef]

7. Kalkuhl, M.; Schwerhoff, G.; Waha, K. Land tenure, climate and risk management. Ecol. Econ. 2020, 171, 106573. [CrossRef]

8. Shanley, P.; Pierce, A.; Laird, S.; Robinson, D. Beyond Timber Certification and Management of Non-Timber Forest Products; Center for International Forestry Research (CIFOR): Bogor Barat, Indonesia, 2008.

9. Huber, P.; Hujala, T.; Kurttila, M.; Wolfslehner, B.; Vacik, H. Application of multi-criteria analysis methods for a participatory assessment on non-wood forest products in two European case studies. For. Policy Econ. 2017, 103, 103-111. [CrossRef]

10. Hamunen, K.; Kurttila, M.; Miina, J.; Peltola, R.; Tikkanen, J. Sustainability of Nordic non-timber forest product-related businesses-A case study on bilberry. For. Policy Econ. 2019, 109, 102002. [CrossRef]

11. Mello, N.G.R.; Gulinck, H.; Broeck, P.V.; Constanza, P. Social-ecological sustainability of non-timber forest products: A review and theoretical considerations for future research. For. Policy Econ. 2020, 112, 102109. [CrossRef]

12. Fisher, B.; Turner, R.K.; Morling, P. Defining and classifying ecosystem services for decision making. Ecol. Econ. 2009, 68, 643-653. [CrossRef]

13. Hein, L.; Koppen, K.; Groot, R.D.; Ierland, E.V. Spatial scales, stakeholders and the valuation of ecosystem services. Ecol. Econ. 2006, 57, 20-228. [CrossRef]

14. Alves, J.G.T. O planejamento governamental e seus reflexos na estrutura fundiária de Mato Grosso (Government planning and its reflexes in the land structure of Mato Grosso). Caminhos De Geografia. 2013, 9, 17-30.

15. De Souza Filho, T.A.; Pedrozo, E.Á.; Paes-de-Souza, M. Produtos Florestais Não-Madeiráveis (PFNMs) da Amazônia: Uma visão autóctone da cadeia-rede da castanha-da-amazônia no estado de Rondônia (Non-Timber Forest Products (NTFPs) from the Amazon: An autochthonous view of the chain-network of the Brazil nut in the state of Rondonia). Rev. De Adm. E Neg. Da Amaz. 2011, 3, 58-74.

16. Hurtienne, T. Agricultura familiar e desenvolvimento rural sustentável na Amazônia. Novos Cad. NAEA 2008, 8, 19-71. [CrossRef]

17. World Wide Foundation (WWF). Desenvolvimento Sustentável No Noroeste de Mato Grosso; WWF: Brasília, Brazil, 2012.

18. Giampietro, M.; Allen, T.F.H.; Mayumi, K. Science for governance: The implications of the complexity revolution. In Interfaces Between Science and Society; Guimaraes-Pereira, A., Guedes-Vaz, S., Tognetti, S., Eds.; Greenleaf Publishing: Sheffield, UK, 2006.

19. Aldrich, S.; Walker, R.; Simmons, C.; Caldas, M.; Perz, S. Contentious Land Change in the Amazon's Arc of Deforestation. Ann. Assoc. Am. Geogr. 2012, 102, 103-128. [CrossRef]

20. Nunes, P.C.; Rugnitz, M.T. Semeando Esperança, Colhendo Bens e Serviços Ambientais: Resultados do Projeto Poço de Carbono; ADERJURAssociação de Desenvolvimento Rural de Juruena: Juruena, Brazil, 2011.

21. Peters, K. Methodological issues in life cycle assessment for remanufactured products: A critical review of existing studies and an illustrative case study. J. Clean. Prod. 2016, 126, 21-37. [CrossRef]

22. Pierce, D.W.; Barnett, T.P.; Hidalgo, H.G.; Das, T.; Bonfils, C.; Santer, B.D. Attribution of declining Western U.S. snowpack to human effects. J. Clim. 2008, 21, 6425-6444. [CrossRef]

23. Maldonado, T.V. The Metabolism of the Amazon Chestnut Productive Chain: An Analysis through the Musiasem Methodology. Ph.D. Thesis, Universidade Federal do Paraná-UFPR, Curitiba, Brazil, 2018.

24. Homma, A.K.O.; Menezes, A.J.E.A. Avaliação de uma Indústria Beneficiadora de Castanha-do-Pará, na Microrregião de Cametá, PA; (Evaluation of a Beneficiary Industry in Castanha-do-Pará, in the Microregion of Cametá, PA); Empresa Brasileira de Pesquisa Agropecuária: Belém, Brazil, 2008.

25. Locatelli, M.; Vieira, A.H.; Gama, M.M.B.; Ferreira, M.G.R.; Martins, E.P.; Silva Filho, E.P.; Souza, V.F.; Macedo, R.S. Cultivo da Castanha-do-Brasil em Rondônia; (Brazil nut cultivation in Rondônia); Embrapa Rondônia: Vilhena, Brazil, 2008.

26. Fischer-Kowalski, M. Society's metabolism-the intellectual history of materials flow analysis, part I 1860-1970. J. Ind. Ecol. 1998, 2, 61-78. [CrossRef]

27. Ayres, R.U.; Kneese, A.V. Production, Consumption, and Externalities. Am. Econ. Rev. 1969, 59, $282-297$.

28. Boyden, S. The impact of civilisation on human biology. Aust. J. Exp. Biol. Med. Sci. 1969, 47, 287-298. [CrossRef]

29. Daly, H.E. The steady-state economy: Toward a political economy of biophysical equilibrium and moral growth. In Toward $a$ Steady-State Economy; Daly, H.E., Ed.; W.H. Freeman: San Francisco, CA, USA, 1973; pp. 325-383.

30. Kneese, A.V. Environmental Pollution: Economics and Policy. Am. Econ. Rev. 1971, 61, 153-166.

31. Meadows, D.L.; Meadows, D.H.; Randers, J.; Behrens, W.W., III. The Limits to Growth; Universe Books: New York, NY, USA, 1972.

32. Newell, J.P.; Cousins, J.J. The boundaries of urban metabolism. Prog. Hum. Geogr. 2015, 39, 702-728. [CrossRef]

33. Gallopoulos, N.E. Industrial ecology: An overview. Prog. Ind. Ecol. 2006, 3, 10-27. [CrossRef]

34. Roberts, B.H. The application of industrial ecology principles and planning guidelines for the development of eco-industrial parks: An Australian case study. J. Clean. Prod. 2004, 12, 997-1010. [CrossRef]

35. Burkett, P. Marx's Ecology and the limits of contemporary ecosocialism. Capital. Nat. Soc. 2001, 12, 126-133. [CrossRef] 
36. Collins, J.; Kinzig, A.; Grimm, N.; Fagan, W.; Hope, D.; Wu, J.; Borer, E. A New Urban Ecology: Modeling human communities as integral parts of ecosystems poses special problems for the development and testing of ecological theory. Am. Sci. 2000, 88, 416-425.

37. McIntyre, N.E.; Knowles-Yánez, K.; Hope, D. Urban Ecology as an Interdisciplinary Field: Differences in the use of 'Urban' Between the Social and Natural Sciences. Urban Ecol. 2008, 49-65.

38. Baccini, P. Understanding regional metabolism for a sustainable development of urban systems. Environ. Sci. Pollut. Res. 1996, 3, 108-111. [CrossRef] [PubMed]

39. Jelinski, L.W.; Graedel, T.E.; Laudise, R.A.; McCall, D.W.; Patel, C.K. Industrial ecology: Concepts and approaches. Proc. Natl. Acad. Sci. USA 1992, 89, 793-797. [CrossRef]

40. Cronon, W. Nature's Metropolis: Chicago and the Great West; W.W. Norton: New York, NY, USA, 1991.

41. Swyngedouw, E. Social Power and the Urbanization of Water: Flows of Power; Oxford University Press: Oxford, UK, 2004.

42. Foster, J.B. Marx's theory of metabolic rift: Classical foundations for environmental Sociology. Am. J. Sociol. 1999, 105, 366-405. [CrossRef]

43. Foster, J.B. The dialectics of nature and Marxist ecology. In Dialectics for the New Century; Ollman, B., Smith, T., Eds.; PalgraveMacmillan: London, UK, 2008; pp. 50-82.

44. Moore, J.W. Environmental Crises and the Metabolic Rift in World-Historical Perspective. Organ. Environ. 2000, 13, 123-157. [CrossRef]

45. Swyngedouw, E. Circulations and metabolisms: (Hybrid) Natures and (Cyborg) cities. Sci. Cult. 2006, 15, 105-121. [CrossRef]

46. Golubiewski, N. Is there a metabolism of an urban ecosystem? An ecological critique. Ambio 2012, 41, 751-764. [CrossRef]

47. Odum, E.P. Energy Flow in Ecosystems: A Historical Review indicates. Am. Zool. 1968, 8, 11-18. [CrossRef]

48. Giampietro, M.; Mayumi, K. Multiple-scale integrated assessments of societal metabolism: Integrating biophysical and economic representations across scales. Popul. Environ. 2000, 22, 155-210. [CrossRef]

49. Giampietro, M.; Mayumi, K. Multiple-scale integrated assesment of societal metabolism: Introducing the approach. Popul. Environ. 2000, 22, 109-153. [CrossRef]

50. Matthews, K.; Blackstock, K.; Buchan, K.; Miller, D.; Rivington, M.; Gilbert, A.; Ibiyemi, A.; Dunglinson, J. D16: Scottish Case Study Report; Finland Futures Research Centre, Turku School of Economics: Turku, Finland, 2010.

51. Scheidel, A.; Giampietro, M.; Ramos-Martin, J. Self-sufficiency or surplus: Conflicting local and national rural development goals in Cambodia. Land Use Policy 2013, 34, 342-352. [CrossRef]

52. Xiaohui, C.; Tiansong, W.; Piano, S.L.; Mayumi, K. China's metabolic patterns and their potential problems. Ecol. Model. 2015, 318, 75-85. [CrossRef]

53. Ginard-Bosch, F.J.; Ramos-Martín, J. Energy metabolism of the Balearic Islands (1986-2012). Ecol. Econ. 2016, 124, 25-35. [CrossRef]

54. Aragão, A.; Giampietro, M. An integrated multi-scale approach to assess the performance of energy systems illustrated with data from the Brazilian oil and natural gas sector. Energy 2016, 115, 1412-1423. [CrossRef]

55. Schwarz, J.; Mathijs, E. Globalization and the sustainable exploitation of scarce groundwater in coastal Peru. J. Clean. Prod. 2017, 147, 231-241. [CrossRef]

56. Giampietro, M.; Gamboa, G.; Lobo, A.; Sorman, A.; Waldron, T. Multi-Scale Integrated Analysis Societal Ecosystem Metabolism (MuSIASEM): User and Client Documentation for MuSIASEM; Turku School of Economics, Finland Futures Research Centre: Turku, Finland, 2008.

57. Giampietro, M.; Mayumi, K.; Ramos-Martin, J. Multi-scale integrated analysis of societal and ecosystem metabolism (MuSIASEM): Theoretical concepts and basic rationale. Energy 2009, 34, 313-322. [CrossRef]

58. Bertolini, G.R.F.; Possamai, O. Proposta de Instrumento de Mensuração do Grau de Consiciência Ambiental, do Consumo Ecológico e dos Critérios de Compra dos Consumidores. Rev. De Cienc. Tecnol. 2005, 13, 17-25.

59. Giampietro, M.; Bukkens, S.G.F. Analogy between Sudoku and the multi-scale integrated analysis of societal metabolism. Ecol. Inform. 2015, 26, 18-28. [CrossRef]

60. Kleene, S.C. Introduction to Metamathematicsi; D. Van Nostrand: London, UK, 1950.

61. Ander-Egg, E. Introducción a Las Técnicas de Ivestigación Social; Editorial Humanitas: Buenos Aires, Argentina, 1978.

62. Creswell, J.W. Qualitative Inquiry and Research Design: Choosing among Five Aproaches; SAGE Publications: Thousand Oaks, CA, USA, 2013

63. Creswell, J.W.; Clark, V.L.P. Designing and Conducting Mixed Methods Research; SAGE Publications: Thousand Oaks, CA, USA, 2011.

64. Maldonado, T.V.; Panhoca, L.; Allievi, F. MuSIASEM analysis structure proposal for micronarratives on extractive productive chains in the Amazon context. Ecol. Indic. 2019, 106, 105509. [CrossRef]

65. Cadillo-Benalcazar, J.J.; Renner, A.; Giampietro, M. A multiscale integrated analysis of the factors characterizing the sustainability of food systems in Europe. J. Environ. Manag. 2020, 271, 110944. [CrossRef] [PubMed]

66. Yin, R.K. Case Study Research and Applications: Design and Methods; Sage: Thousand Oaks, CA, USA, 2017.

67. Hutchings, P.C.; Cuadrado, L.; Ezbakhe, F.; Mesa, B.; Tamekawa, C.; Franceys, R. A systematic review of success factors in the community management of rural water supplies over the past 30 years. Water Police 2015, 17, 963-983. [CrossRef] 
68. Voigt, W.; Perner, J.; Hefin Jones, T. Using functional groups to investigate community response to environmental changes: Two grassland case studies. Glob. Chang. Biol. 2007, 13, 1710-1721. [CrossRef]

69. Fang, X.; Shi, X.; Gao, W. Measuring urban sustainability from the quality of the built environment and pressure on the natural environment in China: A case study of the Shandong Peninsula region. J. Clean. Prod. 2020, 289, 2-14. [CrossRef]

70. Richardson, R.J. Pesquisa Social: Métodos e Técnicas; Atlas: São Paulo, Brazil, 2007.

71. Recalde, M.; Ramos-Martin, J. Going beyond energy intensity to understand the energy metabolism of nations: The case of Argentina. Energy 2012, 37, 122-132. [CrossRef]

72. Brasil, Decreto No 8.618, de 29 de Dezembro de 2015. In Regulamenta a Lei $n^{\circ} 13.152$, de 29 de Julho de 2015, que Dispõe Sobre o Valor do Salário Mínimo e a sua Política de Valorização de Longo Prazo; Diario Oficial [da] República Federativa do Brasil: Brasília, Brazil, 2015.

73. Brazilian Institute of Geography and Statistics. PNAD: IBGE Divulga o Rendimento Domiciliar per Capita 2016; IBGE: Rio de Janeiro, Brazil, 2017; p. 4.

74. Merriam, S.B. Qualitative Research: A Guide to Design and Implementation; Jossey-Bass: San Francisco, CA, USA, 2009.

75. Molina-Maturano, J.; Bucher, J.; Speelman, S. Understanding and evaluating the sustainability of frugal water innovations in México: An exploratory case study. J. Clean. Prod. 2020, 274, 122692. [CrossRef]

76. Eisenhardt, K.M.; Graebner, M.E. Theory Building From Cases: Opportunities And Challenges. Acad. Manag. J. 2007, 50, 25-32. [CrossRef]

77. Mathews Hunt, K. Gaming the system: Fake online reviews v. consumer law. Comput. Law Secur. Rev. 2015, 31, 3-25. [CrossRef]

78. Hervey, T.; Shaw, J. Women, Work and Care: Women's Dual Role and Double Burden in Ec Sex Equality Law. J. Eur. Soc. Policy 1998, 8, 43-63. [CrossRef]

79. Giampietro, M.; Cadillo Benalcazar, J.J.; Di Felice, L.J.; Manfroni, M.; Pérez Sánchez, L.; Renner, A.; Ripa, M.; Velasco Fernández, R.; Bukkens, S.G.F. Report on the Experience of Applications of the Nexus Structuring Space in Quantitative Storytelling; Magic Nexus: London, UK, 2021.

80. Grivins, M.; Tisenkopfs, T.; Stojanovic, Z.; Ristic, B. A Comparative Analysis of the Social Performance of Global and Local Berry Supply Chains. Sustainability 2016, 8, 532. [CrossRef] 